\title{
JCEIB
}

Journal Chemical Engineering and Industrial Biotechnology (JCEIB)

Open Access

Volume 2 pp. 37-46; September 2017

CUniversiti Malaysia Pahang Publisher

DOI: https://doi.org/10.15282/JCEIB-V2-06.29/9/2017/2.2

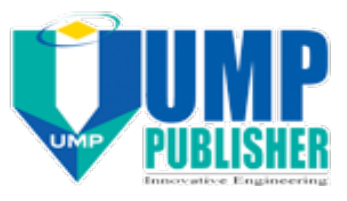

\section{CO-GASIFICATION OF COAL AND EMPTY FRUIT BUNCH (EFB) IN AN ENTRAINED FLOW GASIFICATION PROCESS}

\author{
Wan Muhamad Syafiq Wan Ismail, Ruwaida Abdul Rasid* \\ Faculty of Chemical Engineering \& Natural Resources, Universiti Malaysia Pahang, 26300 Gambang, \\ Pahang, Malaysia \\ *Corresponding author: ruwaida@ump.edu.my \\ Tel.: +609-5492915 Fax.: +609-5492888
}

\begin{abstract}
In Malaysia, empty fruit bunch (EFB) is one of the major biomass source from the palm oil industry. It is an environmental friendly, renewable and sustainable source of energy, which may be used to generate electricity and other forms of energy. EFB may be converted into synthesis gas (syngas) through the gasification process, or mixed with coal through the co-gasification process. Raw EFB usually consists of high moisture content and low energy density compared to coal. Having a mixture of biomass and coal is one of the method to increase the efficiency of the biomass gasification process. Hence, it is the objective of this work to investigate the co-gasification of coal and EFB at various process conditions, whereby, an entrained flow gasifier was used to investigate the effect of the gasification temperature in the range of $700^{\circ} \mathrm{C}-900^{\circ} \mathrm{C}$, for various coal-EFB mixtures on the syngas composition. The produced gas was collected and quantified using gas chromatography. It was found that when the mass ratio of coal to EFB was increased, the production of hydrogen $\left(\mathrm{H}_{2}\right)$, carbon monoxide $(\mathrm{CO})$ and carbon dioxide $\left(\mathrm{CO}_{2}\right)$ also increases. Besides that, the carbon conversion and the higher heating value (HHV) of the gas products also increases with increasing in mass ratio of coal-EFB mixtures. The highest cold gas efficiency (CGE) recorded for coal mixture is $2.72 \mathrm{MJ} / \mathrm{m}^{3}$. Thus, this shows the potential in co-gasification for producing alternative energy to the conventional fossil fuel resources that is depleting.
\end{abstract}

Keywords: Biomass; gasification; empty fruit bunch; coal; entrained flow gasifier.

\subsection{INTRODUCTION}

The reduction of fossil fuel is cause by the increasing of the world energy demand, in which fossil fuel is the primary source. It has been reported that more than $80 \%$ of energy consumption is from the fossil fuel (Aznar et al., 2006). Gasification is one of the most promising technology that can be used to convert various carbonaceous feedstock such as petroleum, coal, biomass (Velez et al., 2009) into synthesis gas (syngas), a mixture of carbon monoxide (CO) and hydrogen $\left(\mathrm{H}_{2}\right)$ as well as other gases such as carbon dioxide $\left(\mathrm{CO}_{2}\right)$ and methane $\left(\mathrm{CH}_{4}\right)$. Co-gasification of coal and biomass, in which a mixture of both fuels may be converted into syngas that can be used as fuels or as a chemical precursor that can reduce the dependency on fossil fuels (Andre et al., 2005; Mohammad and Masnadi, 2015; Pan et al., 2000; Aznar et al., 2006). Although coal has a higher energy content compared to biomass, its utilization has caused serious 
environmental impact locally and globally. The carbon and sulphur content of coal are higher than biomass, as such, harmful gases are release from coal utilization namely, $\mathrm{CO}_{2}$, nitrogen oxides $\left(\mathrm{NO}_{\mathrm{x}}\right)$ and sulphur oxides $\left(\mathrm{SO}_{\mathrm{x}}\right)$ all of which are detrimental for the environment ( $\mathrm{Li}$ et al., 2010). The co-gasification of biomass with coal may be able to reduce the production of these harmful gases and subsequently reduced environmental pollution (Li et al., 2010). The crucial difference between coal and biomass can be seen in term of its volatile matter, fixed carbon and ash. Coal contains less volatile matter, meanwhile biomass has less fixed carbon and less ash compared to coal (Mallick et al., 2017). During co-gasification, several reactions occur similar to the gasification process, such as oxidation, steam and dry reforming, and methanation, producing syngas and other chemical species such as heavy hydrocarbons, tars, solids and pollutant gaseous (Pan et al., 2000; Brar et al., 2012). Table 1 summarizes the reactions.

Table 1: Reactions for co-gasification process (Andre et al., 2005; Brar et al., 2012; Narvaez et al., 1996)

\begin{tabular}{ccc}
\hline Process & Reaction & Heating value $(\mathrm{kJ} / \mathrm{mol})$ \\
\hline Oxidation & $\mathrm{C}+\mathrm{O}_{2} \leftrightarrow \mathrm{CO}_{2}$ & $\Delta H=+408.8$ \\
Partial oxidation & $2 \mathrm{C}+\mathrm{O}_{2} \leftrightarrow 2 \mathrm{CO}$ & $\Delta H=+246.4$ \\
Steam reforming & $\mathrm{CH}_{4}+\mathrm{H}_{2} \mathrm{O} \leftrightarrow \mathrm{CO}+3 \mathrm{H}_{2}$ & $\Delta H=206$ \\
Dry reforming & $\mathrm{CH}_{4}+\mathrm{CO}_{2} \leftrightarrow 2 \mathrm{CO}+2 \mathrm{H}_{2}$ & $\Delta H=247.4$ \\
Water gas & $\mathrm{C}+\mathrm{H}_{2} \mathrm{O} \leftrightarrow \mathrm{CO}+\mathrm{H}_{2}$ & $\Delta H=-131$ \\
Boudouard & $\mathrm{C}+\mathrm{CO}_{2} \leftrightarrow 2 \mathrm{CO}$ & $\Delta H=-172$ \\
Water gas shift reaction & $\mathrm{CO}+\mathrm{H}_{2} \mathrm{O} \leftrightarrow \mathrm{CO}_{2}+\mathrm{H}_{2}$ & $\Delta H=-41.98$ \\
Methanation & $\mathrm{C}+2 \mathrm{H}_{2} \leftrightarrow \mathrm{CH}_{4}$ & $\Delta H=-74.9$ \\
\hline
\end{tabular}

Li et al. (2010), co-gasified pine sawdust and rice straw with coal in a fluidized bed gasifier. The study found that as the biomass ratio increases from 0 to $33 \%$, the $\mathrm{H}_{2}$ production increased, while $\mathrm{CO}$ production was decreased. This can be resulting from the decreasing of carbon content when the biomass ratio increases due to low fixed carbon content in biomass compared to coal. Kumabe et al. (2007) used a fixed bed downdraft gasifier for the co-gasification of Mulia coal and Japanese cedar wood to investigate the effect of various ratios of woody biomass and coal. They found that the biomass ratio had a positive effect on the conversion of the fuels, as it was increased from $59 \%$ to $98 \%$. The $\mathrm{H}_{2}$ production was unfortunately reduced from 47.9 to 37.5 vol.\%, while $\mathrm{CO}$ production was slightly affected with a slight increase from 22.1 to 23.9 vol. $\% . \mathrm{CO}_{2}$ production on the other hand was increased from 6.1 to 33.7 vol.\%.

Pinto et al. (2003) used a fixed ratio of $60 \%$ coal, $20 \%$ pine and $20 \%$ polyethylene for the co-gasification process in a fluidized bed gasifier. The effect of temperature and gasification medium was studied to determine the syngas yield produced. The rise of temperature was detected to influence the reduction of $\mathrm{CO}_{2}$ concentration which can be explained by the dry reforming reaction of $\mathrm{CO}_{2}$ and $\mathrm{CH}_{4}$, which ultimately increased the production of $\mathrm{H}_{2}$. Velez et al. (2009) studied the co-gasification of Colombian biomass and coal in a fluidized bed gasifier. They found that when the temperature was increased from 850 to $900^{\circ} \mathrm{C}$, the concentration of $\mathrm{CO}$ increased while decreased for $\mathrm{CO}_{2}$. This suggests the occurrence of the Boudouard and water gas reactions which caused the increased in the $\mathrm{CO}$ concentration. On the other hand, the methanation 
reaction probably caused the $\mathrm{H}_{2}$ concentration to decrease as the temperature was increased due to $\mathrm{CH}_{4}$ formation.

Andre et (2005), investigated the co-gasification of bagasse wastes with coal using a fluidized bed gasification process to analyze the gas composition and its energetic content. As the temperature was increased to higher than $830^{\circ} \mathrm{C}$, the $\mathrm{H}_{2}$ concentration was increased, while $\mathrm{CO}_{2}$ concentration was decreased. Similarly, this was thought to be due to the Boudouard and the water gas reactions occurring at higher temperature range, while cracking and reforming reactions may contribute to the increased in the $\mathrm{H}_{2}$ formation.

Many of the previous works on co-gasification were conducted using either fluidized bed or fixed bed gasifiers, while limited work was done in entrained flow gasifiers, to the best of our knowledge. Seeing the potential and the flexibility of this type of gasifier, it is the aim of this work to explore and investigate the effect of operating parameter (temperature and mass ratio) on gas yield $\left(\mathrm{H}_{2}, \mathrm{CO}\right.$ and $\left.\mathrm{CO}_{2}\right)$ for cogasification of coal and EFB in an entrained flow gasifier. Compared to other type of gasifiers, an entrained flow gasifier is appearing to be suitable for the joint conversion of biomass and coal (Ali et al., 2017). An entrained flow gasifier can be operated at higher reaction temperature, which is up to $1200^{\circ} \mathrm{C}$ and can achieve high conversion rate in a matter of seconds (Tremel et al., 2013) which also may provide high quality, and tar-free syngas (Xu et al, 2014). In this study, the temperature tested is between $700^{\circ} \mathrm{C}$ to $900^{\circ} \mathrm{C}$ while the biomass ratio values are varied based on mass ratio of biomass to coal which from B0 (100\% coal) to B100 (100\% biomass) at atmospheric pressure.

\section{Materials}

\subsection{MATERIALS AND METHODS}

For this study, EFB was chosen as a raw material due to its abundance in Malaysia and availability, Malaysia being one of the main oil palm producers in the world. EFB was supplied by Kilang Sawit LCSB Lepar Hilir, Pahang, Malaysia and the coal used in this study is Adaro coal, used in Sultan Salahuddin Abdul Aziz Power Station in Kapar, Selangor, Malaysia. Due to its high moisture content of approximately $67 \%$, preprocessing was necessary before the EFB can be utilized. They were washed with tap water to remove undesired compounds, and then manually chopped to smaller pieces before being dried in the oven at $100^{\circ} \mathrm{C}$ for 24 hours. This is to ensure that the moisture content is reduced and consistent (Sabil et al., 2013). The coal was manually chopped as well, ground and sieved to get the particles in a consistent size. The EFB and coal mixtures were based on mass ratio, with the total mass sample is 20 grams. The provision of the mass ratio is shown in Table 2.

Table 2: The allocation of the mass ratio between EFB and coal

\begin{tabular}{ccc}
\hline Mass ratio & Mass of EFB $(\mathrm{g})$ & Mass of coal $(\mathrm{g})$ \\
\hline B0 & 0 & 20 \\
B10 & 2 & 18 \\
B30 & 6 & 14 \\
B50 & 10 & 10 \\
B100 & 20 & 0 \\
\hline
\end{tabular}




\section{Gasifier}

The gasification experiments were performed in a laboratory-scale entrained flow gasifier, operating at atmospheric pressure. Air was used as the gasifying agent, at fixed equivalence ratio (ER) through manual loading. ER may be defined as the oxygen ratio that required for gasification to oxygen required for stoichiometric combustion at given amount of biomass (Narvaez et al., 1996). Figure 1 shows the schematic flow diagram for co-gasification of coal and EFB. The furnace (7) can withstand temperature up to $1000^{\circ} \mathrm{C}$. It is built with cylindrical shape with an inside diameter of $4.5 \mathrm{~cm}$ and the length of $50 \mathrm{~cm}$ that was made of stainless steel. The screw feeder (5) is used to feed the samples (4) with feeding rate set at $1.02 \mathrm{~g} / \mathrm{s}$ for $20 \mathrm{~g}$ of samples. The temperature controller (6) is used to control the temperature of the furnace. Air (2) enters the furnace in co-current flow with the samples along with nitrogen (1), the carrier gas. The cyclone (10) is used to remove ash and char from the gas and transfer them into the ash collector $(8,9)$ which is connected to the bottom of the cyclone. The condenser $(11)$ is used to cool down the hot product gas that passed through it. The gas was collected in an air tight gas bag which has the maximum capacity of $1 \mathrm{~L}$ and would fill up every $10 \mathrm{~s}$, after which it was replaced with another empty gas bag until the end of the experiment. Each experiment was repeated at least three times to obtain precise data. The sample gas then was analyzed by using Gas Chromatography Thermal Conductivity Detector, GC-TCD G1530N which was used to determine the composition of the produced gas.

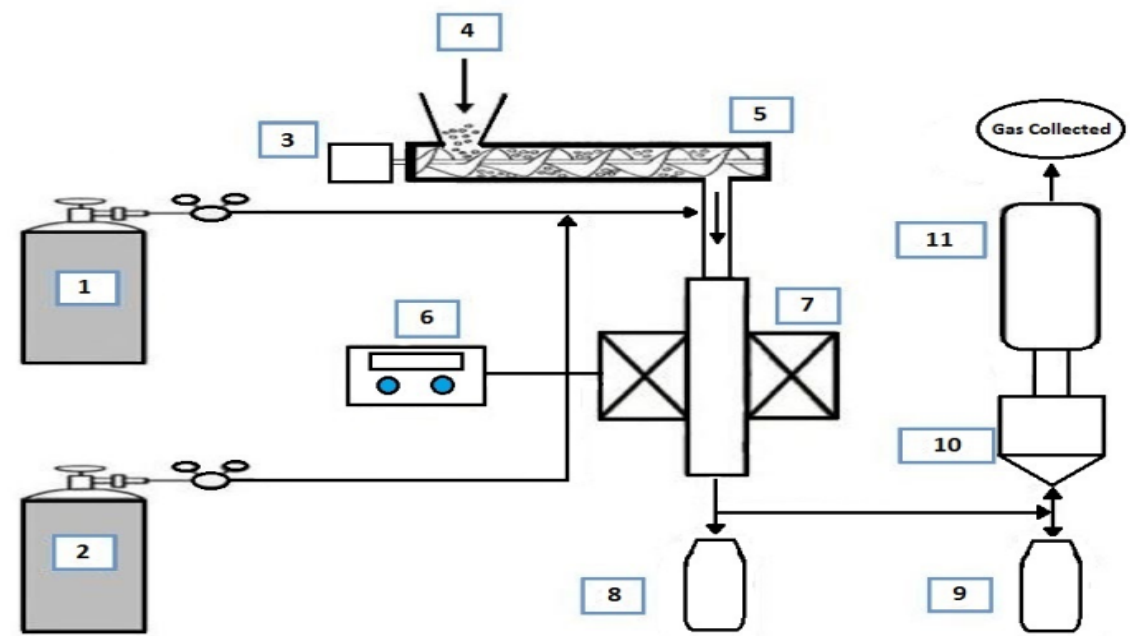

Figure 1: Schematic flow diagram for co-gasification of coal and EFB

\section{Sample Analysis}

Preliminary analysis for raw samples are required to determine the content of the samples. Ultimate analysis (UA) is one of the analysis can be used to determine the weight percentage for $\mathrm{C}, \mathrm{H}, \mathrm{N}, \mathrm{S}$, and $\mathrm{O}$ in the samples, and were done using the CHNS Analyzer.

The higher heating value (HHV) of the produced syngas is calculated based on equation (1) (Waldheim \& Nilsson, 2001) where it depends on the amount of combustible gases produced as follows:

$$
H H V=\frac{\left(12.75 \mathrm{H}_{2}+12.63 \mathrm{CO}+39.82 \mathrm{CH}_{4}\right)}{100}
$$


Where $\mathrm{H}_{2}, \mathrm{CO}$, and $\mathrm{CH}_{4}$ is in mol.\%. Based on the obtained values of the HHV of the product gas, as well as the HHV of the solid fuels, the cold gas efficiency (CGE) can subsequently be calculated as in equation (2) (Karmakar and Datta, 2011) as follows:

$$
C G E=\frac{H H V \text { of product gas }}{H H V \text { of fuel }} \times 100 \%
$$

Where HHV of product gas $\left(\mathrm{MJ} / \mathrm{Nm}^{3}\right)$ and $\mathrm{HHV}$ of fuel in $(\mathrm{MJ} / \mathrm{kg})$.

\section{Analysis of the Coal and EFB}

\subsection{RESULTS AND DISCUSSIONS}

The UA for pure coal and mixtures for coal and EFB are recorded in Table 3. It can be seen that the $\mathrm{C}$ content for coal is higher compared to mixture of $\mathrm{EFB}$ and coal. However, EFB and coal mixture has higher H, N, S and O content.

Table 3: The ultimate analysis for coal and mixture of EFB and coal

\begin{tabular}{ccc}
\hline Ultimate analysis & \multicolumn{2}{c}{ Samples } \\
\cline { 2 - 3 } (wt.\%) & Coal & EFB + Coal \\
\hline Carbon (C) & 77.30 & 52.413 \\
Hydrogen (H) & 5.31 & 5.991 \\
Nitrogen (N) & 1.93 & 6.722 \\
Sulphur (S) & 1.27 & 0.174 \\
Oxygen (O) & 14.2 & 34.700 \\
\hline
\end{tabular}

\section{The Influence of Mass Ratio on Syngas Production}

Figure 2 illustrates the effect of mass ratio on production of $\mathrm{H}_{2}$ at temperature 700,800 and $900^{\circ} \mathrm{C}$. The $\mathrm{H}_{2}$ produced was increased initially, but then slightly decreased when temperature reached $800^{\circ} \mathrm{C}$. This may be due to the methanation reaction $\left(C+2 \mathrm{H}_{2} \leftrightarrow\right.$ $\mathrm{CH}_{4}$ ) where carbon compound reacts with $\mathrm{H}_{2}$ to form $\mathrm{CH}_{4}$ (Velez et al., 2009). For the co-gasification reaction, the coal and biomass mixture contains higher volatile matter and less moisture compared to pure coal, hence producing less $\mathrm{H}_{2}$ (Li et al., 2010; Velez et al., 2009). Figure 3 and 4 shows the trends of different temperature at various mass ratio on the production of $\mathrm{CO}_{2}$ and $\mathrm{CO}$ respectively. The production of $\mathrm{CO}_{2}$ was slightly decreased while $\mathrm{CO}$ was increased throughout the experiments at various conditions. The decreasing of $\mathrm{CO}_{2}$ production can be explained by the consumption of $\mathrm{CO}_{2}$ by dry reforming reaction of $\mathrm{CH}_{4}\left(\mathrm{CH}_{4}+\mathrm{CO}_{2} \leftrightarrow 2 \mathrm{CO}+2 \mathrm{H}_{2}\right)$ (Andre et al., 2005; Pinto et al., 2003; Franco et al., 2003), which causes the increase of $\mathrm{CO}$ and $\mathrm{H}_{2}$ production as the temperature increased. Furthermore, the water gas shift reaction $\left(\mathrm{CO}+\mathrm{H}_{2} \mathrm{O} \leftrightarrow \mathrm{CO}_{2}+\mathrm{H}_{2}\right)$ and the Boudouard reaction $\left(\mathrm{C}+\mathrm{CO}_{2} \leftrightarrow 2 \mathrm{CO}\right)$ are believed to be the most influential reactions to increase the $\mathrm{CO}$ production while reducing the formation of $\mathrm{CO}_{2}$. This is consistent with study by other researchers (Andre et al., 2005; Pan et al., 2000; Velez et al., 2009). 
Journal of Chemical Engineering and Industrial Biotechnology V2(2017)37-46

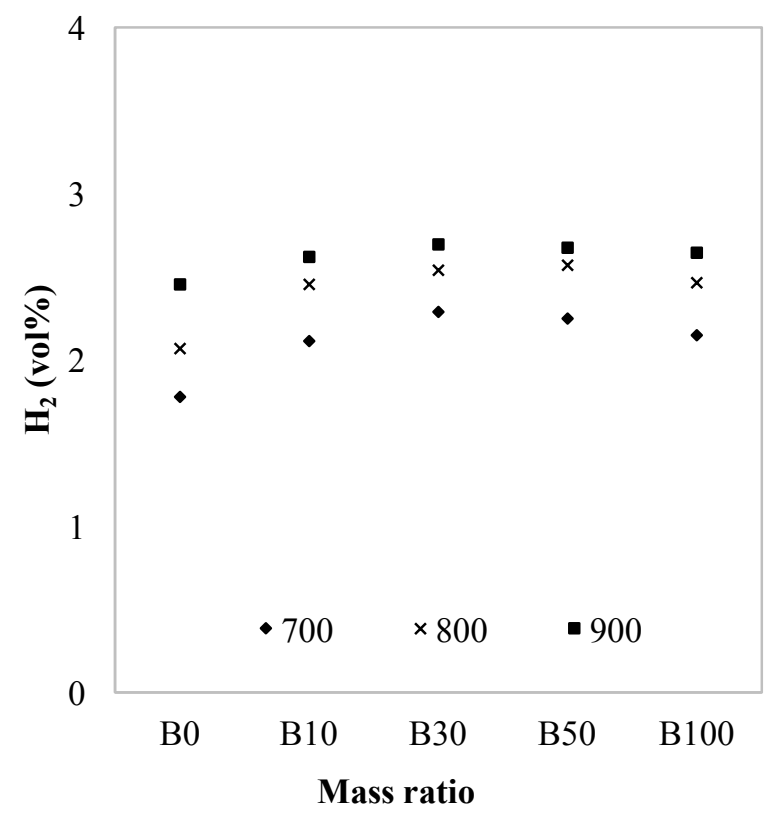

Figure 2: The vol.\% for $\mathrm{H}_{2}$ composition at different mass ratio

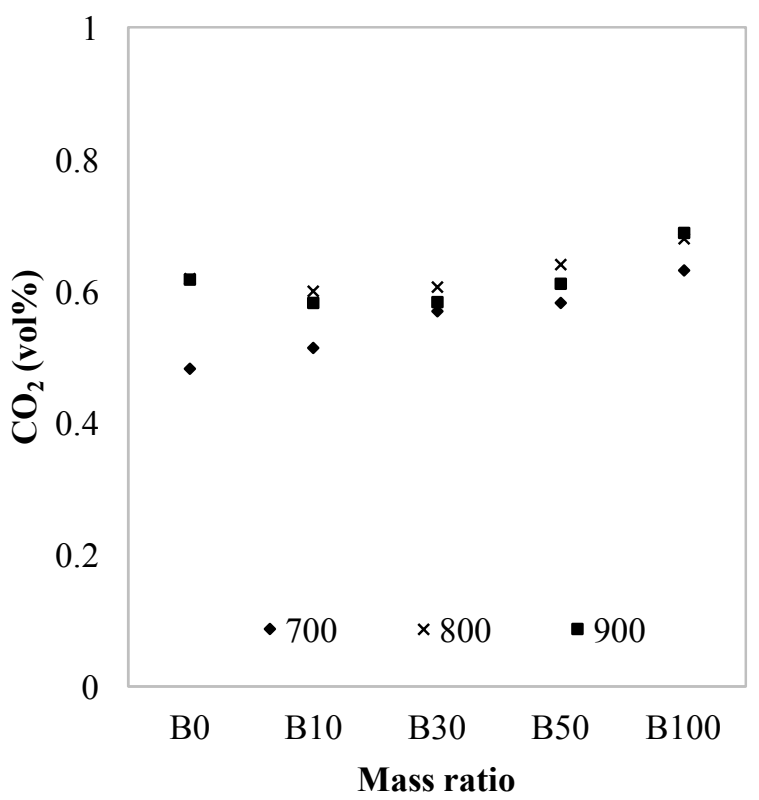

Figure 3: The vol.\% for $\mathrm{CO}_{2}$ composition at different mass ratio 


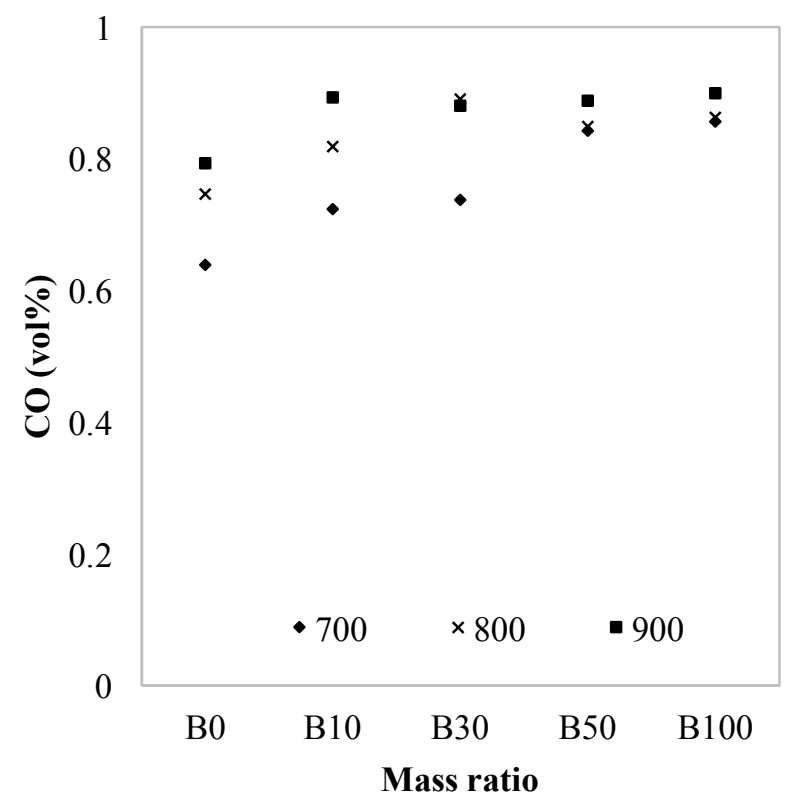

Figure 4: The vol.\% for CO composition at different mass ratio

\section{The Influence of Mass Ratio on the HHV and CGE}

Figure 5 shows the HHV values for the co-gasification of EFB and coal at various mass ratios and temperatures. The HHV of fuel is defined as the quantity of heat release by the combustion of specific amount of fuel under normal conditions (McKendry, 2002). However, as the mass ratio increase from B30 to B100, the HHV is observed to be slightly decreasing. According to Andre et al. (2005) and Pinto et al. (2003) this phenomenon may be caused by the reduction production of methane and hydrocarbon, due to the reduced amount of fixed carbon in coal (increased biomass). The effect of CGE value for co-gasification at various mass ratios and temperature is illustrated in Figure 6. The cold gas efficiency (CGE) is defined as the ratio of the HHV of the produced syngas over the HHV of the original fuel in percentage as defined by Karmakar and Datta (2011) in equation (2). The CGE shows a positive trend when the operating temperature was increased from 700 to $900^{\circ} \mathrm{C}$ as well as when the mass ratio of biomass to coal was also increased. This is due to the increased in the production of the syngas, $\mathrm{H}_{2}$ and $\mathrm{CO}$ (Hernandez et al., 2010). A synergetic effect was also observed at B50, where at this point, the HHV and CGE were at their highest value. Similar observation was made by Ding et al. (2014) which determined the strongest synergetic effect at blending ratio of $50 \%$. 


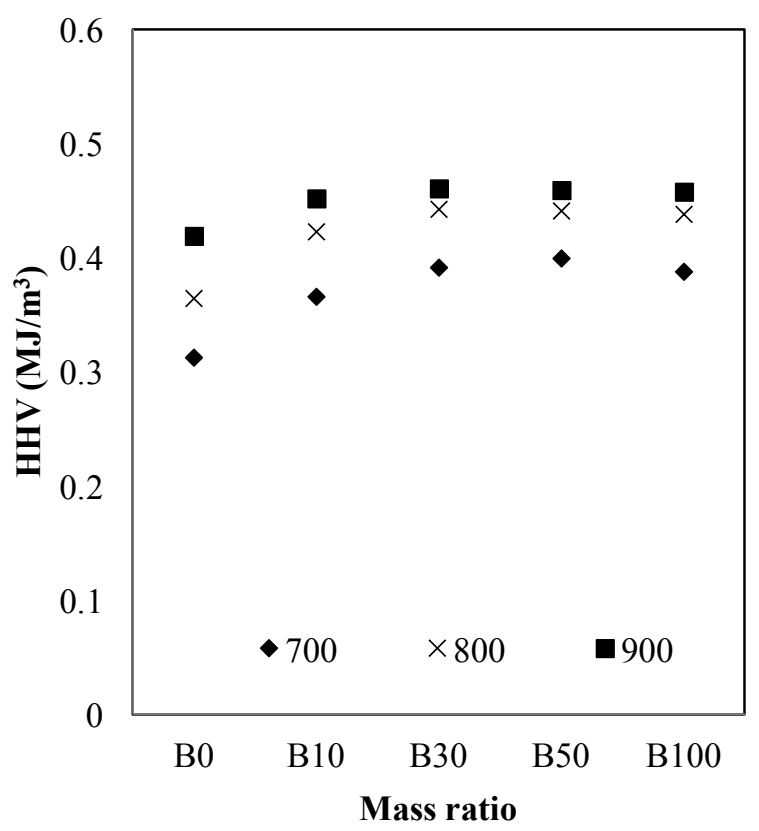

Figure 5: The HHV value for co-gasification at different mass ratio

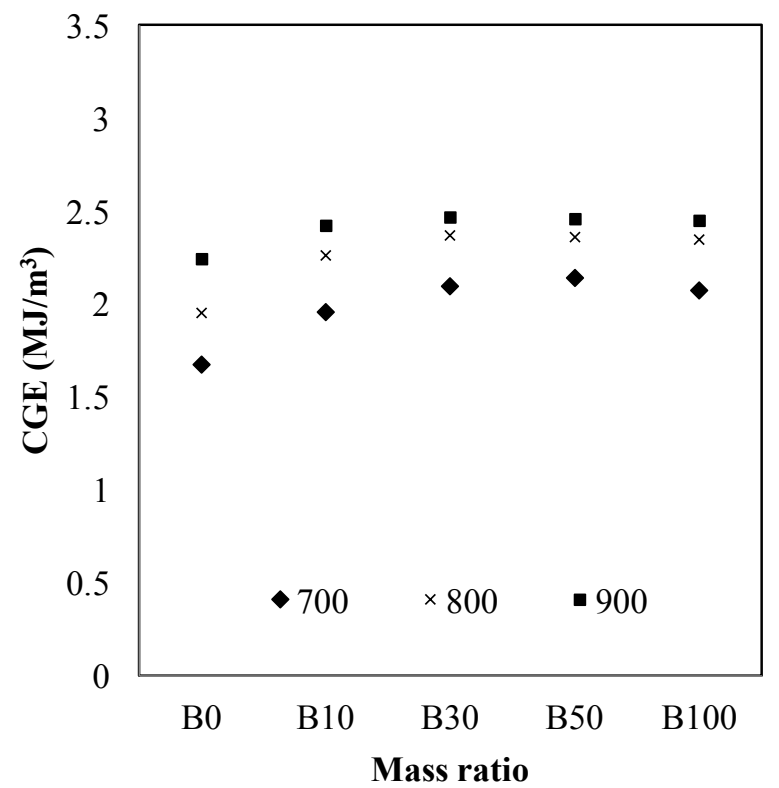

Figure 6: The CGE value for co-gasification at different mass ratio

\subsection{CONCLUSION}

The co-gasification of coal and EFB in an entrained flow gasifier in this study, evaluates the production of $\mathrm{H}_{2}, \mathrm{CO}$ and $\mathrm{CO}_{2}$ over different operating temperature and coal to EFB ratio (B0 - B100). Over the range of operating conditions tested, the highest temperature of $900^{\circ} \mathrm{C}$ and by using the mass ratio of B50 was observed to produce the highest amount of syngas, as well as the highest heating values, where at this point also the synergistic effect was observed. This work confirmed that the mixture of coal and 
EFB is favorable to be further explored as an alternative energy source because not only that can reduce the dependency on fossil fuels, it may be reduce the environmental effect of pure coal utilization.

\section{ACKNOWLEDGEMENT}

This project was supported by the Ministry of Higher Education Malaysia (RDU140134) and Universiti Malaysia Pahang (RDU140323). The authors also thank the Faculty of Chemical Engineering and Natural Resources, Universiti Malaysia Pahang for providing the lab space to conduct the trials, as well as TNB Research Bangi, especially Dr. Nor Fadzilah Othman for the Adaro coal samples.

\section{REFERENCES}

Ali, D. A., Gadalla, M. A., Abdelaziz, O. Y., Hulteberg, C. P., \& Ashour, F. H. (2017). Co-gasification of coal and biomass wastes in an entrained flow gasifier: Modelling, simulation and integration opportunities. Journal of Natural Gas Science and Engineering 37, 126-137.

Andre R., Pinto F., Franco C., Dias M., Gulyurtlu I., Matos M., \& Cabrita I. (2005). Fluidised bed cogasification of coal and olive oil industry wastes. Fuel, 1635-1644.

Aznar, M., Caballero, M., Corella, J., Molina, G., \& Toledo, J. (2006). Hydrogen Production by Biomass Gasification with Steam-O2 Mixtures Followed by a Catalytic Steam Reformer and a CO-Shift System. Energy \& Fuels, 1305-1309.

Brar, J. S., Singh, K., Wang, J., \& Kumar, S. (2012). Cogasification of Coal and Biomass: A Review. International Journal of Forestry Research, Volume 12.

Ding, L., Zhang, Y., Wang, Z., Huang, J., \& Fang, Y. (2014). Interaction and its induced inhibiting or synergistic effects during co-gasification of coal char and biomass char. Bioresource Technology 173, 11-20.

Franco C., Pinto F., Gulyurtlu I., \& Cabrita I. (2003). The study of reactions influencing the biomass steam gasification process. Fuel, 835-842.

Hernandez, J. J., Aranda-Almansa, G., \& Serrano, C. (2010). Co-Gasification of Biomass Wastes and Coal-Coke Blends in an Entrained Flow Gasifier: An Experimental Study. Energy \& Fuels 24, 2479-2488.

Karmakar, M., \& Datta, A. (2011). Generation of hydrogen rich gas through fluidized bed gasification of biomass. Bioresource Technology, 1907-.

Kumabe, K., Hanaoka, T., Fujimoto, S., Minowa, T., \& Sakanishi, K. (2007). Co-gasification of woody biomass and coal with air and steam. Fuel 86, 684-689.

Li, K., Zhang, R., \& Bi, J. (2010). Experimental study on syngas production by co-gasification of coal and biomass in a fluidized bed. International Journal of Hydrogen Energy 35, 2722-2726.

Mallick, D., Mahanta, P., \& Moholkar, V. S. (2017). Co-gasification of coal and biomass blends: Chemistry and engineering. Fuel 204, 106-128.

McKendry, P. (2002). Energy production from biomass (part 1): Overview of biomass. Bioresource Technology, 83 (1), 37-46.

Mohammad S., \& Masnadi J.R. (2015). From fossil fuels towards renewables: Inhibitory and catalytic effects on carbon thermochemical conversion during co-gasification of biomass with fossil fuels. Applied Energy, 196-209.

Narvaez, I., Orio, A., Aznar, M., \& Corella, J. (1996). Biomass gasification with air in an atmospheric bubbling fluidized bed. Effect of six operational variables on the quality of the produced raw gas. Ind Eng Chem Res, 2110-2120.

Pan, Y., Velo, E., Roca, X., Manya, J., \& Puigjaner, L. (2000). Fluidized-bed co-gasification of residual biomass/poor coal blends for fuel gas production. Fuel 79, 1317-1326.

Pinto F., Franco C., Andre R., Tavares C., Dias M., \& Gulyurtlu I. (2003). Effect of experimental conditions on co-gasification of coal, biomass and plastics wastes with air/steam mixtures in a fluidized bed system. Fuel, 1967-1976.

Sabil, K. M., Aziz, M. A., Lal, B., \& Uemera, Y. (2013). Synthetic indicator on the severity of torrefaction of oil palm biomass residues through mass loss measurement. Applied Energy, 821826.

Tremel, A., Becherer, D., Fendt, S., Gaderer, M., \& Spliethoff, H. (2013). Performance of entrained flow and fluidised bed biomass gasifiers on different scales. Energy Conversion and Management 69, 95-106. 
Journal of Chemical Engineering and Industrial Biotechnology V2(2017)37-46

Vélez, J., Chejne, F., Carlos, F., Eder, J., \& Carlos, A. (2009). Co-gasification of Colombian coal and biomass in fluidized bed: An experimental study. Fuel 88, 424-430.

Waldheim, L., \& Nilsson, T. (2001). Heating value of gases from biomass gasification. Nyköping: IEA Bioenergy Agreement.

Xu, S., Ren, Y., Wang, B., Xu, Y., Chen, L., Wang, X., \& Xiao, T. (2014). Development of a novel 2stage entrained flow coal dry powder gasifier. Applied Energy 113, 318-323. 